\title{
Chinese photographers and their clientele in the Netherlands Indies, 1890-1940
}

\author{
LIESBETH OUWEHAND
}

\begin{abstract}
This article examines the position of Chinese photographers in the visual colonial landscape. The Chinese toekang potret were involved in both commissioned photographs and the production of commercial images, but the latter was less widespread. Contrary to the image that Chinese photographers' clients were from the lower strata of society, this article shows that they were commissioned by the European, Chinese and Javanese elite. The image materiality of the portraits reveals the visual traces of circulation and exchange. Hence, the Chinese photographers were indirectly involved in these elite networks as well.
\end{abstract}

KEYWORDS

Commercial photographers; materiality; Chinese; Netherlands Indies.

\section{INTRODUCTION $^{1}$}

This article examines Chinese professional photographers and their clientele from the 1890s, when the first Chinese photographers opened their studios, until the outbreak of World War II. ${ }^{2}$ Among the earliest and most longrunning examples in the KITLV collection are the photographs made by the Batavia-based photographer Tan Tjie Lan. Tan Tjie Lan opened his studio at Pasar Baroe 86 around 1894 and remained active in the same street until about 1947. About 135 Chinese studio photographers have been identified

1 I am grateful to Tom van den Berge and Susie Protschky for their remarks and suggestions on this article. I would like to thank Willem van der Molen for the translation of the Javanese captions into Dutch in KITLV photo album 1194.

2 All examples discussed in the article are derived from the collection of the Royal Netherlands Institute of Southeast Asian and Caribbean Studies (KITLV) which is kept at the Leiden University Libraries.

LIESBETH OUWEHAND was trained as an anthropologist at Universiteit Leiden. She works on the KITLV (Koninklijk Instituut voor Taal-, Land- en Volkenkunde, Royal Netherlands Institute of Southeast Asian and Carribean Studies) photo collection at the Leiden University Libraries. Her book Herinneringen in beeld; Fotoalbums uit Nederlands-Indië (Leiden: KITLV Press) was published in 2009. She published articles on topics such as disaster photography and musical encounters in photography in the Netherlands Indies. Liesbeth Ouwehand can be contacted at: l.ouwehand@library.leidenuniv.nl.

(C) 2017 Faculty of Humanities, Universitas Indonesia

LIESBETH OUWEHAND | DOI: 10.17510/wacana.v18i2.587. 
in the KITLV collection. Not all studios had recognizably Chinese name, for example, Promemoria in Bondowoso, owned by Liem Too Tjiong, or Studio Malang ran by Ong Kian Bie. Therefore it is very likely thatthe collection holds more images produced in Chinese studios. Besides commissioned portraits, as did their European counterparts, photographic studios also sold instant or commercial images of landscapes and town views .

In the literature on professional photographers based in the Netherlands Indies commencing from the mid-nineteenth century, illustrious European photographic studios tend to attract the lion's share of the attention. With a few exceptions such as Gerrit Knaap on Javanese photographer Céphas (Knaap 1999) and Karen Strassler on Chinese professional and amateur photographers in late-colonial and postcolonial Indonesia (2007, 2008, 2010 and 2015), non-European photographers active in the Netherlands Indies remain under-exposed.

Since the photographic landscape in the Indies was certainly not the exclusive field of European photographers, the purpose of this article is to analyse how the networks of Chinese photographers and their clientele affected the social position of the photographers. It raises the question of who and what was being photographed by Chinese photographers? How do images made by Chinese photographers reflect colonial encounters? To what extent can a Chinese gaze be traced in images made by Chinese photographers? In connection to the latter question, Morris (2009: 9) gives an account of Scottish photographer John Thomson, who had met some photographers in nineteenth-century China. The Chinese photographers insisted that the sitter should be photographed as a whole, so that the viewers could see his or her physical stature. As Christopher Pinney (1997: 95-97) makes clear in his Camera Indica, it would be too simple to contrast European and Indian photographic practices in reading the Indian visual landscape. He has shown that both the European and Indian aesthetic traditions played a key role in studio portraiture. Aesthetic values were influenced not only by British and Indian photographers, sitters from different ethnic backgrounds also had a hand in this (Pinney 1997: 72-97). Pinney offers an alternative history in the study of colonial photography, a field which was previously dominated by European perspectives; as if the visual colonial landscape was the sole terrain of European photographers.

In order to study the Chinese photographers and their different clientele European, Indonesian, Eurasian, and Chinese - I shall discuss three different categories which can be distinguished from a survey of the professional studios. The first category consists of commissioned photographs which were taken in studios. The second category is made up of portraits made in situ. The third category comprises commercial images, that is instant photographs of, for example, landscapes and town views. This article is not restricted to photographs, consideration is also given to advertisements the photographers placed in newspapers. Before discussing the commissioned portraits and commercial images, it is important to have some idea of how 
Chinese photographers were perceived in the colonial era and this will be done by drawing on colonial sources and more recent studies.

\section{Chinese IMAGINING}

Seventy-seven Chinese photographers, over 50 percent, in the KITLV collection were based in Java. Sumatra and Celebes come in second and third place respectively with twenty-one and nineteen Chinese photographers. ${ }^{3}$ Most photographers were located in urban areas, in cities such as Batavia, Jogjakarta, Medan, Padang, and Makassar. However, isolated areas were also not shunned by the Chinese toekang potret. Song Koang Photographers operated on Big Karimoen, a small island in the Riouw Archipelago. In the eastern part of the Netherlands Indies, Jong Kong owned a studio in Ambon around the turn of the nineteenth century. Even Soemba had its professional photographer; Wa Tjioe worked in Waingapoe in the 1930s. Although it would be presumptuous to take the Chinese photographers in the KITLV collection as representative sample for the whole body of Chinese photography in the colony, it is not surprising that, as the administrative and economic centre of the colony, Java attracted the most toekang potret, although, as said, more remote areas also had a commercial appeal.

Strassler (2010: 82-83) has said that most first generation Chinese photographers in the Indies were natives of Canton. These Cantonese immigrants had usually apprenticed themselves to already established Chinese photographers in, for example, Hong Kong or Singapore, before leaving for the Indies. An apprenticeship was often inextricably linked to familial ties. Lee Brothers Photographers, owned by the brothers Tat Loon, Tit Loon and Shui Loon, opened their first studio under the name Kuan Heng Photo Studio in Singapore before 1875. As business was slow, Tit and Tat Loon moved to Soerabaja, leaving the Singapore studio to Shui. In the following decades more studios were opened in Singapore, Kuala Lumpur and Java by the brothers, their sons and in partnership with cousins from the Canton area. Three studios in the Indies were run by the Lee family, Lee Yauw Ming in Magelang in the 1930s, Mee Lan Fotograaf in Bandoeng and the Dutch India Chinese Photographers Union in Batavia (Liu 1995: 7-19).

In the early 1920s, fifteen-year-old Ong Kian Bie was taught photography in Malang by two uncles. Later, he was apprenticed to one of his uncles who owned studios in Madioen and Malang. After his uncle died, Ong Kian Bie inherited his business in which he continued to work under the name of Foto Studio Malang (Tan-Ong 1996). Strassler (2008: 417, 2010: 82-83) has demonstrated the familial networks of Chung Hwa Studio in Semarang and Liek Kong in Jogjakarta, thereby revealing the Asian routes by which photographic technology was transferred to and within the Archipelago and its neighbouring countries. Moreover, she notes the key role Chinese photographers played in the spread of photographic technology. In short,

3 Since the photographers discussed in this article were active during the colonial period, I shall use colonial (former) geographical names and spellings. 
its introduction and development was not solely an European achievement.

The Dutch photographic journal Lux regularly paid attention to photography in the Indies. Detrimental tropical conditions, such as humidity and vermin, and their influence on photographic equipment were a recurring theme and the presence of Chinese inhabitants is also mentioned in this context. Radersma (1901: 442), for example, recounts about how he ordered a camera and an enlarger through a Chinese carpenter. An amateur photographer and resident of Kediri, Straatman, advises that amateurs who were not able to make photographic prints themselves would do best turn to a Chinese toekang potret, because they would develop plates and make prints at modest prices. One extra advantage was that Chinese studios could be found nearly everywhere (Straatman 1915: 205).

The link between Chinese photographers and affordable or even cheap prices is also mentioned in another issue of $L u x$, in which Kreuger claims that Chinese photographers attracted poorer clients. With the exception of the local elite, the greater part of the clientele of their studios consisted of native residents (Kreuger 1923: 32-33). The idea that Chinese studios worked for lower prices than their European counterparts and therefore attracted a less elite clientele, be they indigenous, Dutch, Eurasian or Chinese, is echoed in the thrust of modern literature on commercial photography in the Indies as well. Nieuwenhuys (1988: 7) says that Chinese photographers worked in the same tradition as their European counterparts, using the same types of backdrops and props in the studios, but they charged lower rates. Given the fact that they had less capital than the more famous European studios, competition with the latter was ruled out (Wachlin 1989: 124). Furthermore, since the photographers from Canton were of modest origins, they did not have access to the Javanese and European upper classes (Strassler 2008: 415). From this evidence it would seem that commercial photographic studios reflected the colonial social strata; European studios served the European community and local and Asian elites, whereas the rest of the population had their portraits taken by the Chinese toekang potret. In order to explore whether this image of Chinese photographers is also reflected in the KITLV collection, we shall first look at the sitters who visited their studios.

\section{A visit TO A CHINESE PHOTOGRAPHIC STUDIO}

Image 1 shows a Chinese family portrait taken around 1900 in the studio of Tan Tjie Lan. Both father and mother are dressed in Chinese attire. The mothers' feet are bound. The two daughters wear sarongs and an Indies kebaja and a Chinese-style kebaja respectively. The son wears a Chinese jacket. To the right and left are two Indonesian servants who complete the family photo. The backdrop in the photograph refers to the interior of an European-style manor house. Unquestionably, this family photo is not an example of a type portrait, an anonymous instant photograph on sale to Europeans as an exotic souvenir. The first clue is the size of the image. Type portraits were often mounted on a carte-de-visite, a stiff card about $10.5 \times 6.5 \mathrm{~cm}$. The studio portrait of the 
Chinese family is mounted on a large card of $33 \times 25 \mathrm{~cm}$. The second hint is the attention which has been paid to the finishing; all jewellery of the women and the buttons of the white kebaja (middle) are painted with a yellow dye indicating gold. The presence of the servants suggests that the family were members of the well-to-do section of the Chinese community. The provenance of the photo is unknown and no notes which might give an insight into the date, occasion or names of the portrayed have been jotted down on the card.

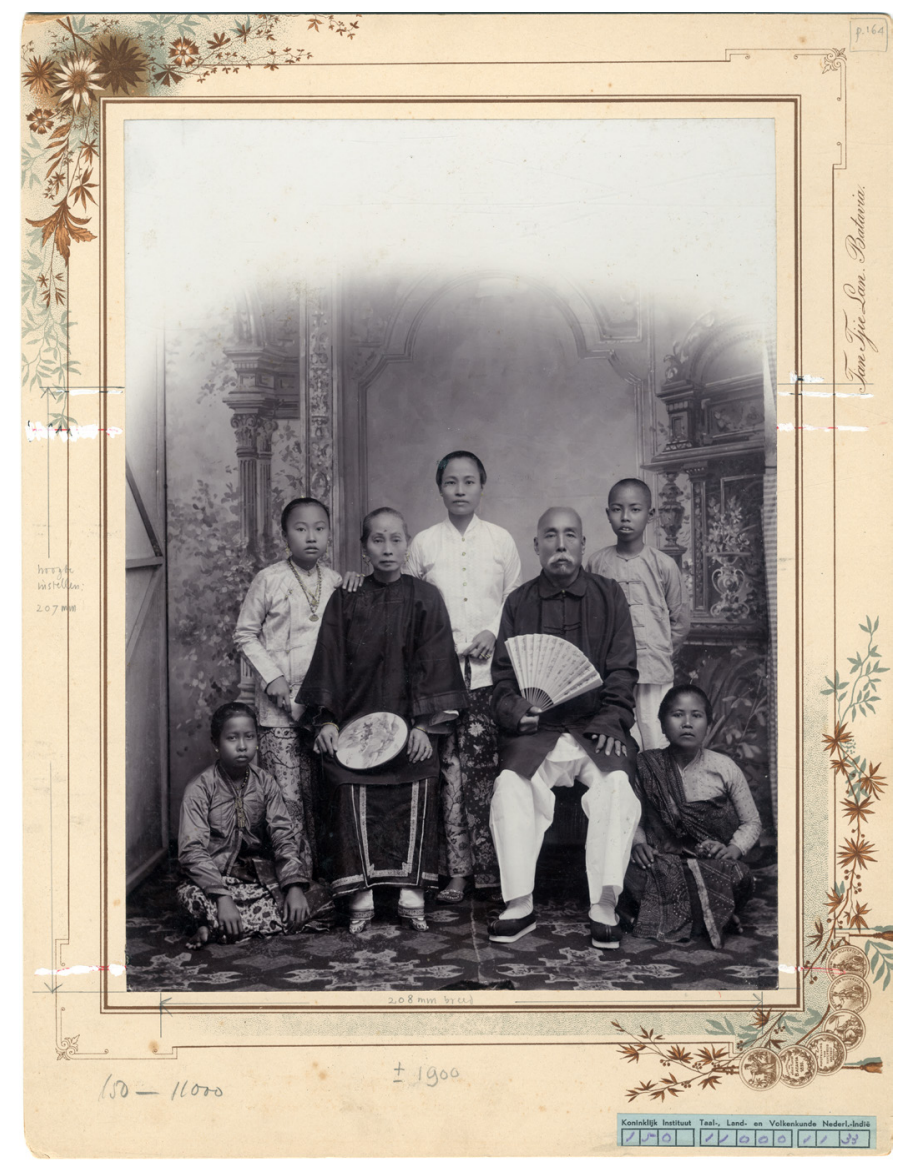

Image 1. Studio photo of a Chinese family with two Indonesian domestic workers in Batavia around 1900 (photographer: Tan Tjie Lan; KITLV collection: 408060).

In my description of Image 1, I have considered almost the entire image content of the photograph. However, in reading photographs such as Image 1 , it is useful not to look at image content alone. As Edwards and Hart (2004: 3-4) suggest, the materiality of a photograph is just as important. The image materiality consists of such features as the photographic technique, presentational forms such as cabinet cards, notes or captions, and "physical traces of usage and time". ${ }^{4}$ Furthermore, in studying the materiality of the 
photograph, the social biography should be taken into account (Edwards and Hart 2004: 4). A photograph is in a continuous process of exchange, usage and changing meaning.

The Chinese family in Image 1 were not anonymous when they had their portrait taken by Tan Tjie Lan. However, at a certain moment in time the family portrait was added to the KITLV collection and since then has lived what one might call an institutional life. Traces of its present life can be found on the front of the card. Nieuwenhuys discusses the photo in one of his Tempo doeloe publications (1988: 164). In order to prepare for the publishing process, Nieuwenhuys has jotted down lines and measurements on the card, as a guideline for the publisher. Even though the materiality of Image 1 is limited to the card and any information on its circulation through time is unclear, the KITLV collection does hold examples in which the materiality is more emphatically articulated and hence casts more light on the social biography of the photograph; a social biography which gives more insight on the position of the Chinese photographers in the Indies.

The social biography of the photograph began at the moment the customer(s) entered a studio to have their portrait taken. The captions in an album or notes on the back of a loose image often explain the reason of the visit.

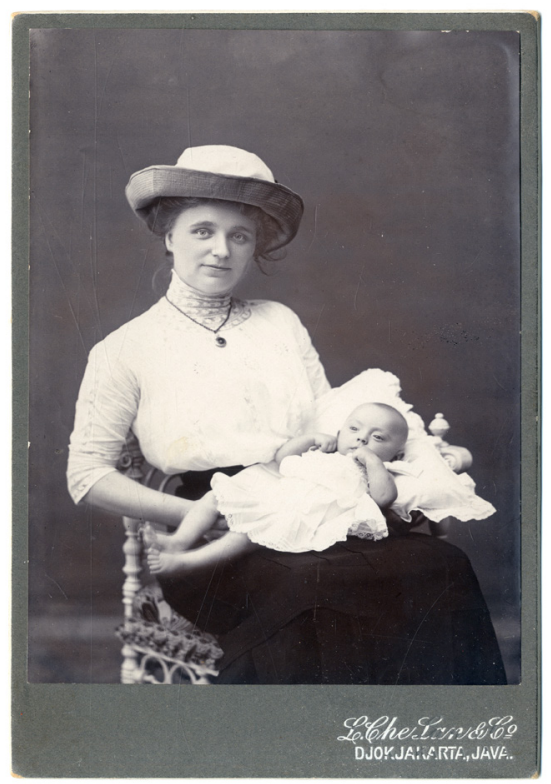

Image 2. Studio portrait of a woman with baby Loes in Jogjakarta around 1910 (photographer: Che Lan; KITLV collection: 178684).

Image 2 by Che Lan in Jogjakarta, for example, was made around 1910 when new-born Loes, on her mother's lap, was three months and three days old, as the annotation at the back of the cabinet card explains. This is a cabinet card

mounted on a card of $16 \times 11 \mathrm{~cm}$. 
whose function was to be a personal souvenir to commemorate Loes' early life. Furthermore, the clothing worn by the portrayed might give more information about the occasion. This is the case in Image 3. Three friends visited the Che Lan Studio in April 1920 to record their visit to a bal masqué. Events such as the birth of a child or a special party were memorialized photographically by those who could afford a visit to a photographic atelier. These were occasions considered worthy of tangible personal souvenirs in the form of cabinet cards. Portrait cards such as Images 2 and 3 were very suitable for exchanging with friends and family. Visual traces of circulation and exchange will be discussed in more detail later.

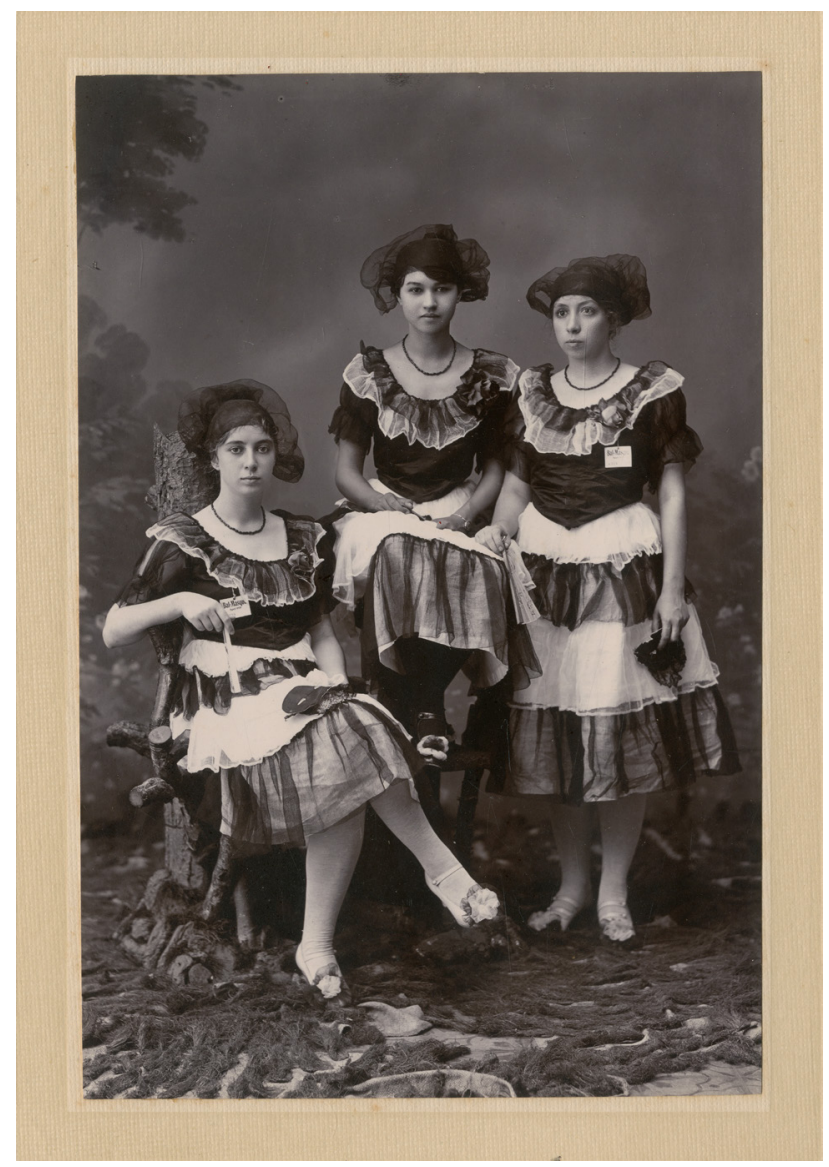

Image 3. Studio portrait of three women dressed for a bal masqué in 1919 (photographer: Che Lan; KITLV collection: 179243).

Besides clothing, studio materials such as backdrops and furnishings added to the souvenir value as well. As Pinney (1997: 88-90) and Strassler (2015: 200) explain, clothing and studio material gave the sitter(s) the opportunity to perform in front of the camera and signify possible projections of themselves.

Looking at the iconography of the backdrops available, the Europeanstyle manor house interior we have seen in Image 1 is a frequently recurring 
background. In Image 4 this interior is thrust even more into the foreground it seems, since the Eurasian family posing in front do not fill the complete backdrop. The interior was completed by a curtain on the left and real plants. The photograph was made by Wah Seng who operated studios in Menado and Makassar.

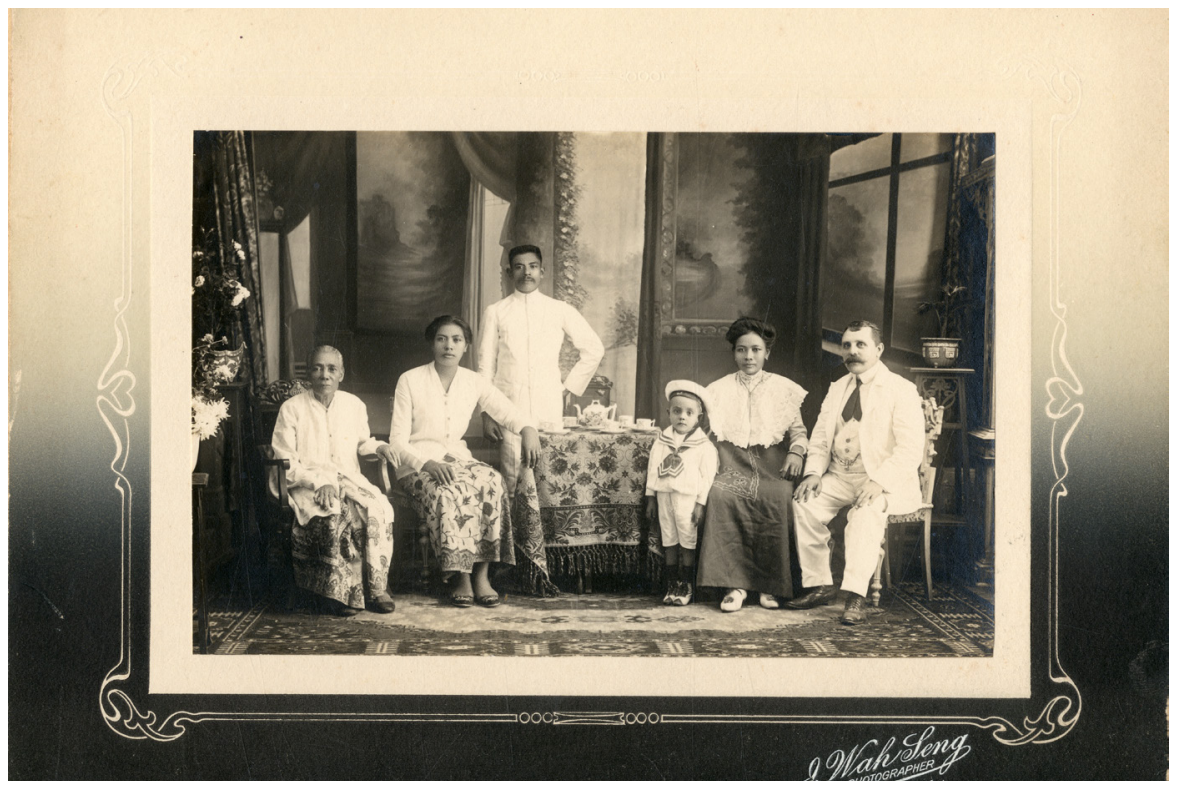

Image 4. Studio photo of an Eurasian family having tea in Menado on 20 August 1915. Dirkje standing (third person from the right) (photographer: Wah Seng; KITLV collection: 182811).

Image 4 was made in the Menado studio in 1915. Indies elements were added to the European scene: a table covered with a batik cloth on which a tea-set was placed. The mixture of European and Indies elements in the scene is also shown in the clothing worn by the sitters. The Indies part is represented by the two women wearing sarong and kebaja. The rest of the party is dressed in European, partly colonial, garb. Protschky (2012: 44-47) has described the striking, repeated photographic depictions of European and Javanese families taking tea in the garden or on the veranda as representations of domesticity. Examples of tea-drinking scenes in a studio are rare. Displays of domesticity could probably be more easily arranged in a real home. Assuming that a photo is a joint construction of both photographer and sitter, the chosen backdrop, the furnishings and clothing in Image 4 suggest a cosy domestic scene in an elite manor house setting.

The Eurasian family in Image 4 is anonymous. Apart from the first name of the boy, Dirkje, the names of the other members are unknown. As the annotation on the back of the photo card reveals, this particular copy of the image was addressed to "Brother Dirk and spouse. From your nephew Dirkje in the East. Negri Timoor, Celebes". Two related photographs, also 
taken in the Wah Seng studio, of Dirkje and his mother around 1915 and an individual portrait of Dirkje taken in 1922, were also sent to family members. This information is clearly conveyed in the notes on the back of the cards. The image of Dirkje in 1922 was addressed to his grandfather living in Ermelo, a village in the Netherlands. Carefully composed studio portraits such as Image 4 were made in order to keep in touch with family members living elsewhere in the Archipelago or in Holland.

Apart from European interiors, European landscapes are also frequently seen. Tan Tjie Lan used an alpine landscape, which appealed not only to European customers, but also to Indonesians. ${ }^{5}$ Image 5, made around 1910, is a carte-de-visite on which a woman is portrayed wearing velvet kebaja and sarong with a rujak sente motif. Her jewellery and foot-rest indicate that she was from a good family. The European landscape gave the Indonesian woman the chance to perform, suggesting a visit to a geographically distant region.

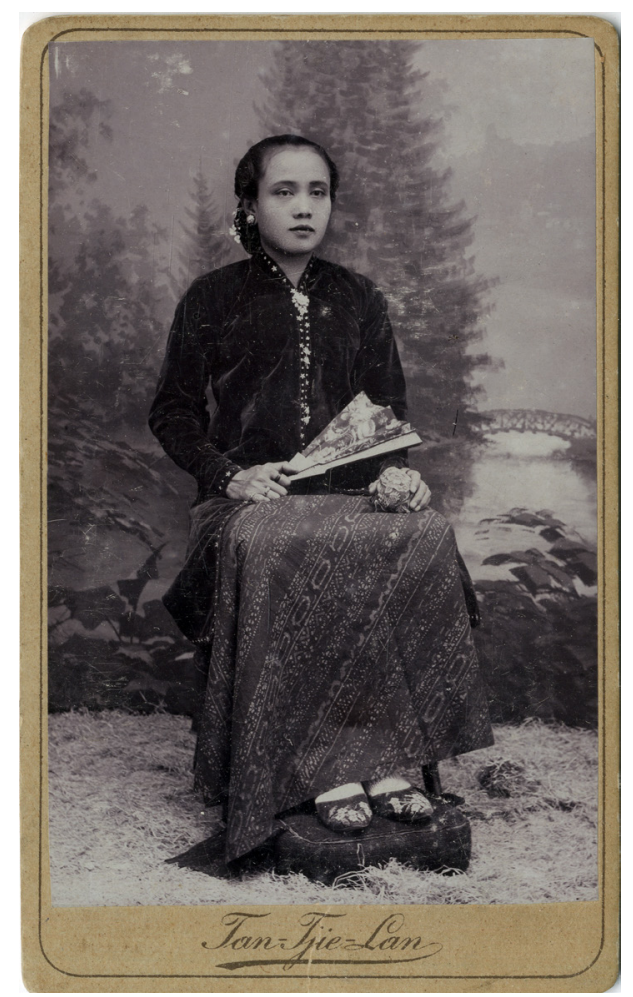

Image 5. Studio portrait of a woman posing against Alpine landscape backdrop in Batavia, around 1910 (photographer: Tan Tjie Lan; KITLV collection: 408010).

So far the backgrounds discussed have not been typically Chinese. The European interiors and landscape backdrops were also used in Europeanrun studios; not surprising, considering the fact that these backdrops were 
imported from Europe (Strassler 2008: 419-420). Naturally, the Indies details in furnishings and the clothing of the portrayed distinguishes the studio portraits made in the Indies from the ones taken in Europe. There were, however, backdrops available which were typically Chinese; they were imported from China, for example, from Shanghai (Strassler 2010: 85).

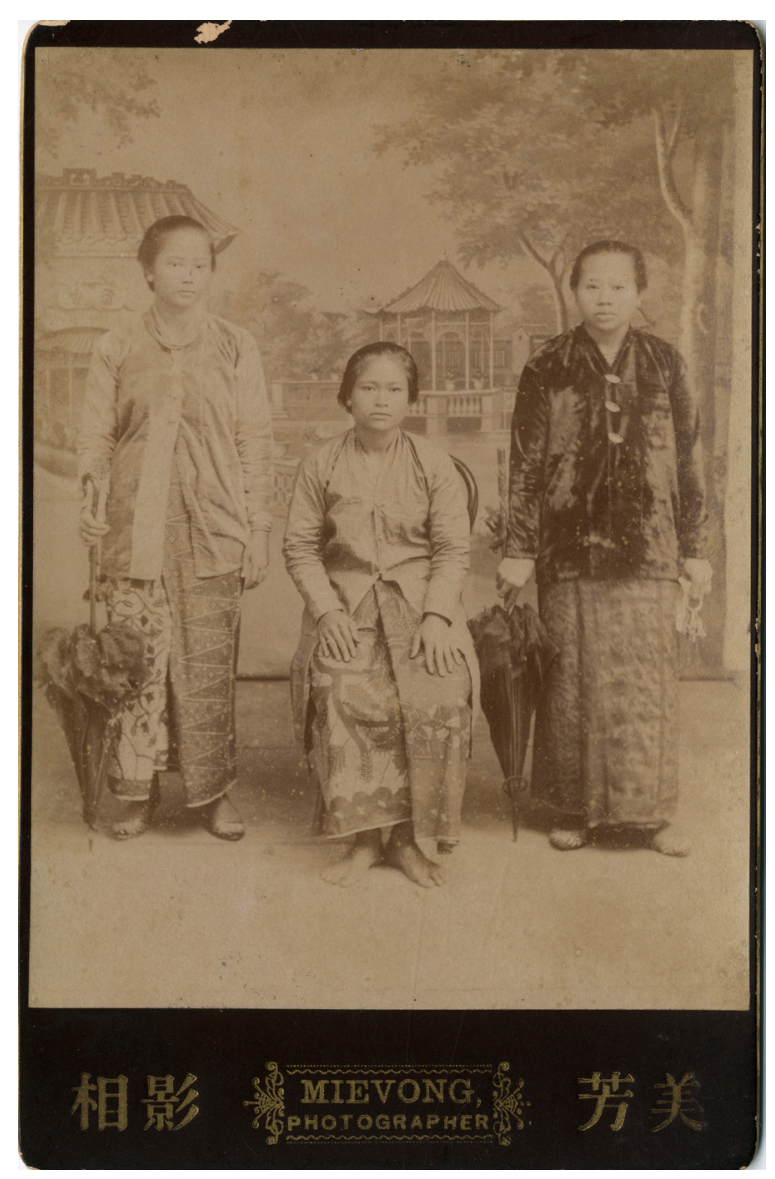

Image 6. Three Indonesian women posing against a Chinese style backdrop, around 1890 (photographer: Mievong; KITLV collection: 178633).

Image 6, taken around 1900 in the Mievong studio, is a cabinet card with three Indonesian women posing in front of a Chinese pavilion. It would be interesting to know why these women chose a Chinese backdrop. Mievong is relatively unknown. It is possible that he ran only a small studio and could offer no choice in backdrop. 


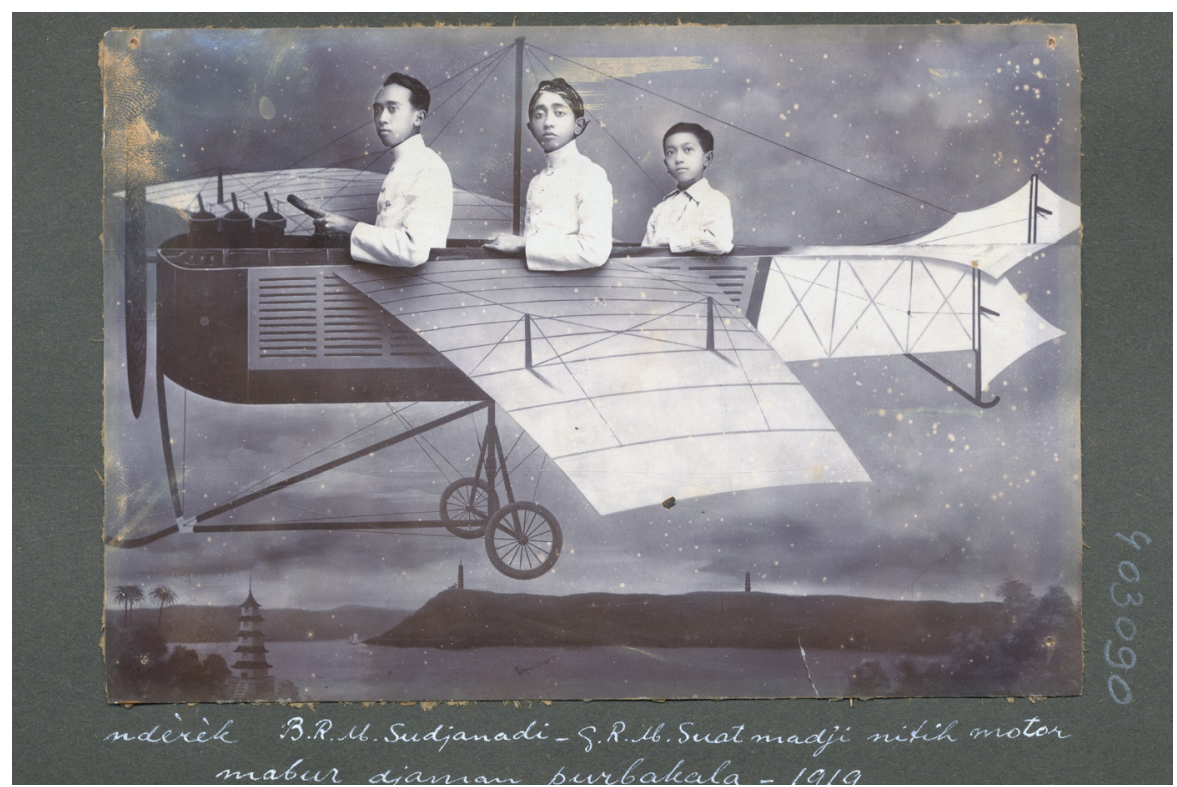

Image 7. Studio photo made in 1919 of B.R.M. Sudjanadi, G.R.M. Suatmaji, and an anonymous young man posing "in a pre-historic airplane" (photographer: Che Lan; KITLV collection: 403090).

A Chinese pavilion also appears in the left corner in Image 7. The most striking feature of the photograph taken by Che Lan in 1919 is the aeroplane. The three young Javanese men are connected to the kraton in Jogjakarta. The status of being able to take a trip by air is also underlined in the caption in Javanese: "Together with B.R.M. Sudjanadi, G.R.M. Suatmaji in a pre-historic aeroplane". The intended viewer of the photo is possibly the anonymous third young man in the picture. ${ }^{6}$

Image 8 was made in the same series, possibly during the same session: "Five prisoners escape by aeroplane". The identical aeroplane is used against a different (European) background. Such a pronounced feature as an aeroplane gave the visitor(s) to a studio the chance to realize an almost undreamed of journey by air; in reality something reserved for the happy few. Furthermore, as Strassler (2015: 2004-206) explains, icons of modernity, such as aircraft offered the sitter the opportunity to present themselves as modern subjects. Moreover, the sitters were given the chance "to pose new possibilities for themselves" and to those who viewed the photograph (Strassler 2015: 200). This last remark is especially interesting, since both aviation studio photos are part of a family album with images taken in and around the kraton in Jogjakarta. The majority of the photographs in the album consist of snapshots Nevertheless a few professional studio photos have also been integrated into the album, thereby making these studio photos "their own". The humorous

6 The same party posed against a harbour backdrop, leaning on against a column and on a balustrade: "Sailing sailing-boats in the background, painted near the harbour (but not for real)" (KITLV collection: 403091). 
captions make it clear that the snapshot album was intended to be viewed in an intimate family sphere.

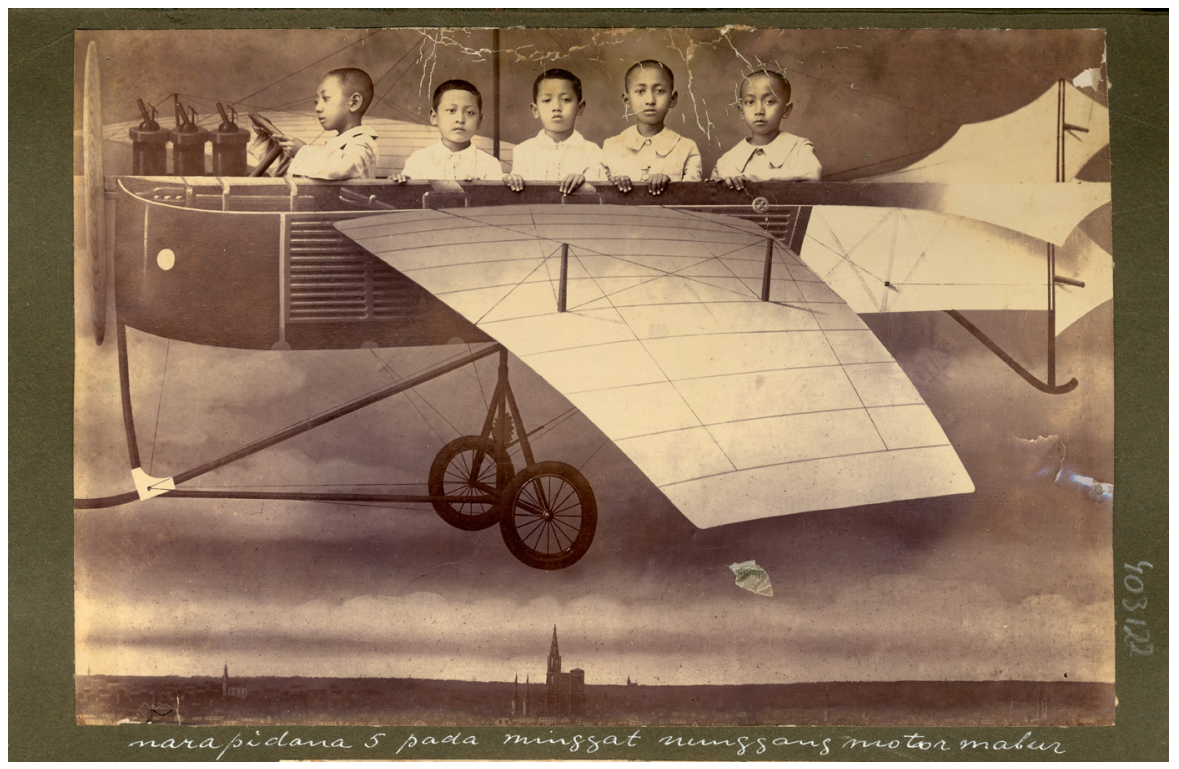

Image 8. Five Javanese children posing against an airplane backdrop in 1919 (photographer: Che Lan; KITLV collection: 403122).

European and Chinese backdrops projecting modernity helped create a space in which sitters could project new, temporal states of being. Sitters portrayed against a plain background put more emphasis on themselves.

Image 9 was made by the Solo-based photographer King Ming in the mid-1920s. Kandjeng Pangeran Ario Poerbonagoro, a military commander in the kraton of Solo, and his wife pose in Javanese military attire and a sarong and kebaja respectively. Two copies of the same photograph are part of the KITLV collection, in which they ended up via a dealer. ${ }^{7}$ Both copies are mounted on cards produced for the King Ming studio. The fact that the cards vary in appearance suggests that Poerbonagoro probably ordered the images at different times, possibly for different reasons and intended for different recipients. ${ }^{8}$ As the back of the card reveals, Image 9 was intended for exchange. Poerbonagoro glued his business card on the back, which makes personal use unlikely (Image 10).

7 The same photograph can be found under KITLV collection: 159107.

8 Photographers usually kept the negatives of the photos taken, to make the re-ordering of an image easier. 


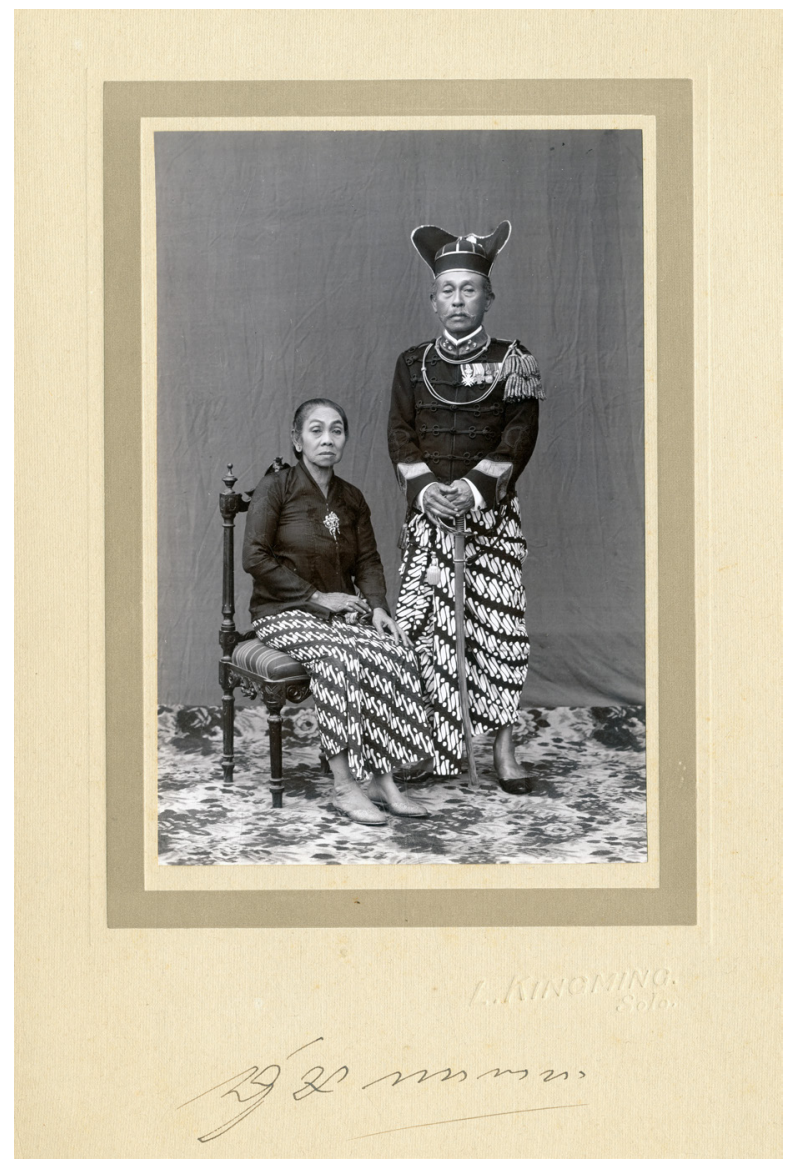

Image 9. Studio portrait of K.P.A. Poerbonagoro, military commander in the kraton of Solo, and his wife, around 1925 (photographer: King Ming; KITLV collection: 182808).

Poerbonagoro and his wife gave their portrait to relations within their network. The KITLV holds two other portraits on which Poerbonagoro and his wife had been photographed individually by King Ming. These photos were given to Mr Popelier, Resident of Krawang. ${ }^{9}$ His work shows that Chinese photographers like King Ming were actively involved in maintaining elite networks of European and Javanese customers by providing suitable portraits, for example, on carte-de-visite or cabinet cards.

As we have seen, Chinese photographers entertained clients from different social strata in their studios, including the Chinese, Javanese, and European elites. In the studios, the sitters were given the opportunity to try new possibilities. Their performance was purely temporary, in the sense that the result choreographed in the studio was different to their life lived outside the studio. The carefully composed photographs were taken home as personal souvenirs and continued their "lives", for example, as objects for exchange, his wife respectively. 
as was very often the case for images mounted on cards. As will be shown in the next section, Chinese photographers were called upon by all sorts and conditions of clients to take their pictures outside the studio. At first glance portraits made outside the studio in the context of the home, for example, might seem more "true to life".

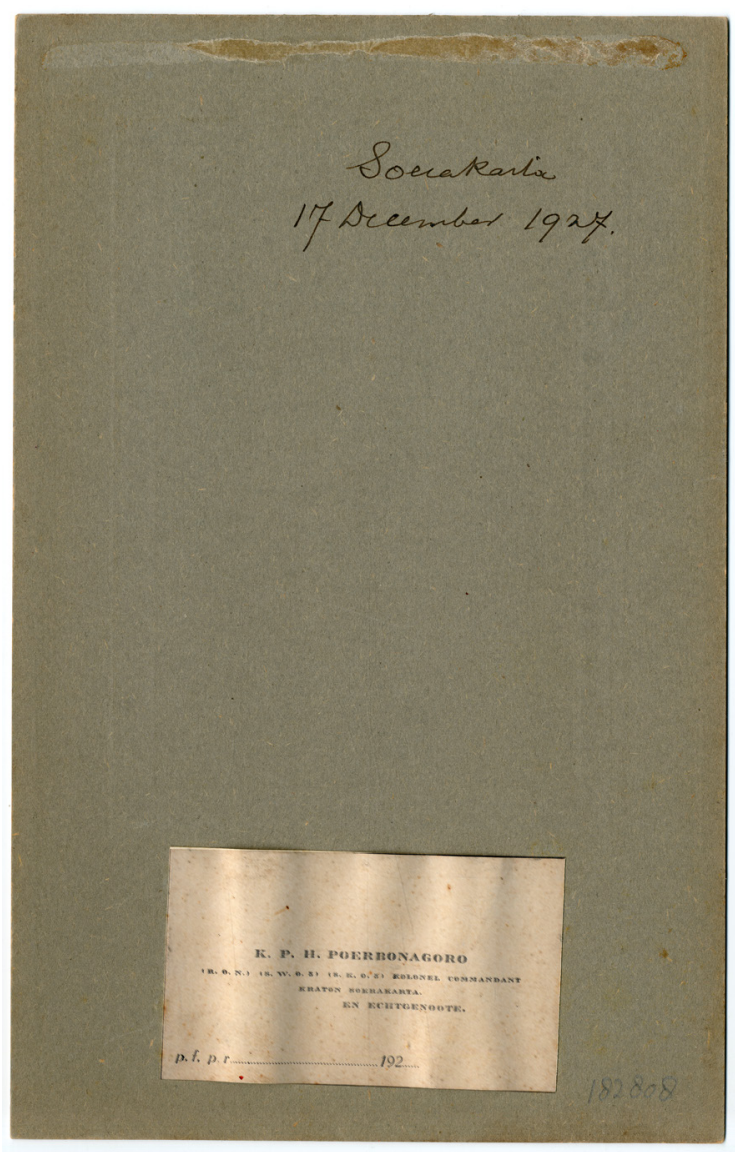

Image 10. Business card of K.P.A. Poerbonagoro glued on the back of the photo card by the King Ming studio (KITLV collection: 182808).

\section{COMMISSIONED PHOTOGRAPHS ON LOCATION}

Photographer Wah Seng portrayed three sons of Assistant-Resident H.T Damsté in their garden in Makassar (Image 11). On the back of the photographic card the full names and dates of births have been jotted down as well as the date on which the photograph was taken: 28 June 1914. 


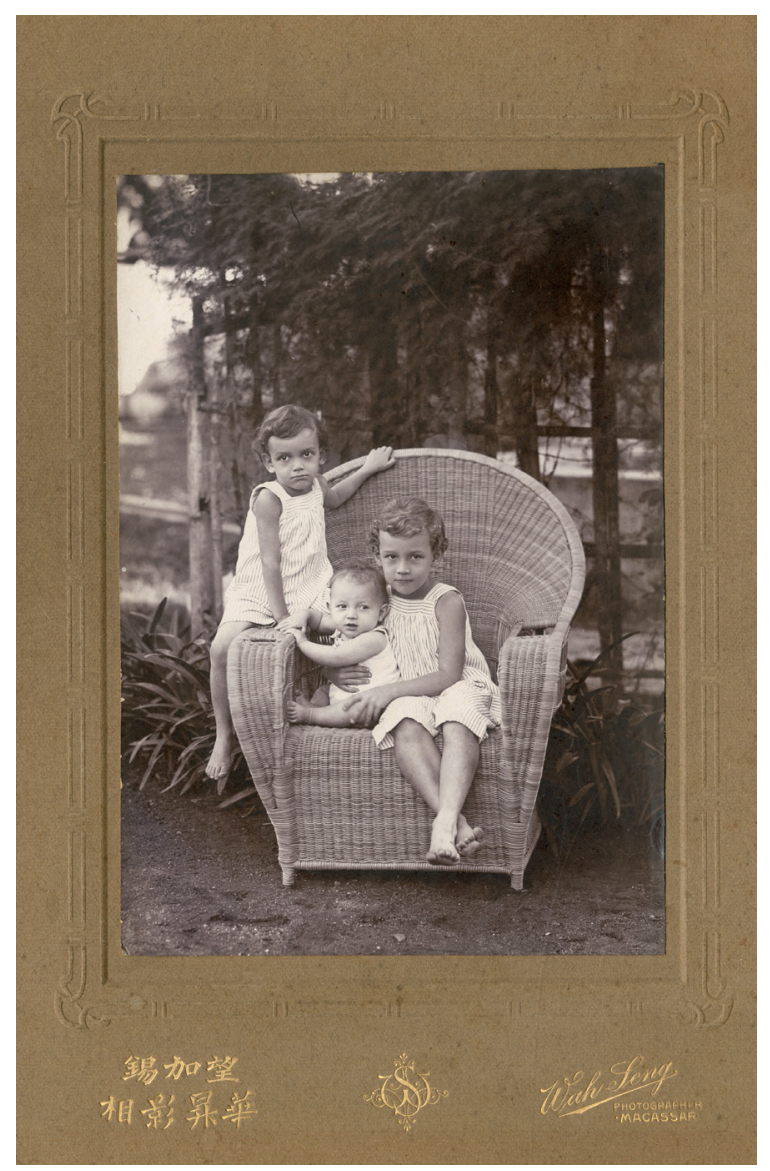

Image 11. Three Damsté brother in their garden in Makassar, June 1914 (photographer: Wah Seng; KITLV collection: 179247).

The KITLV collection contains more photographs which once belonged to Damsté. They were donated to the Institute by his wife in 1955. However, this family photo took another route into the collection; it was recently obtained through a dealer. On the back of the image, the dealer explains that the photograph portrays three of the five Damste children. This information was intended to assist the person adding the photograph to the archive. From the back it is impossible to deduce for which viewer the full names and dates of birth were intended, however exchange with family members or friends living overseas might be a possibility. The photographic souvenir portrays the Damsté children fairly informally; the lightly clad children are in a relaxed pose grouped in and around a chair. Given the fact that the photograph was taken in their garden adds to the general informality.

Not all commissioned photographs taken in the vicinity of the home were informal. On Christmas day 1915, Wah Seng took a photograph of the extended Mandias family in Makassar in front of the veranda (Image 12 ). 


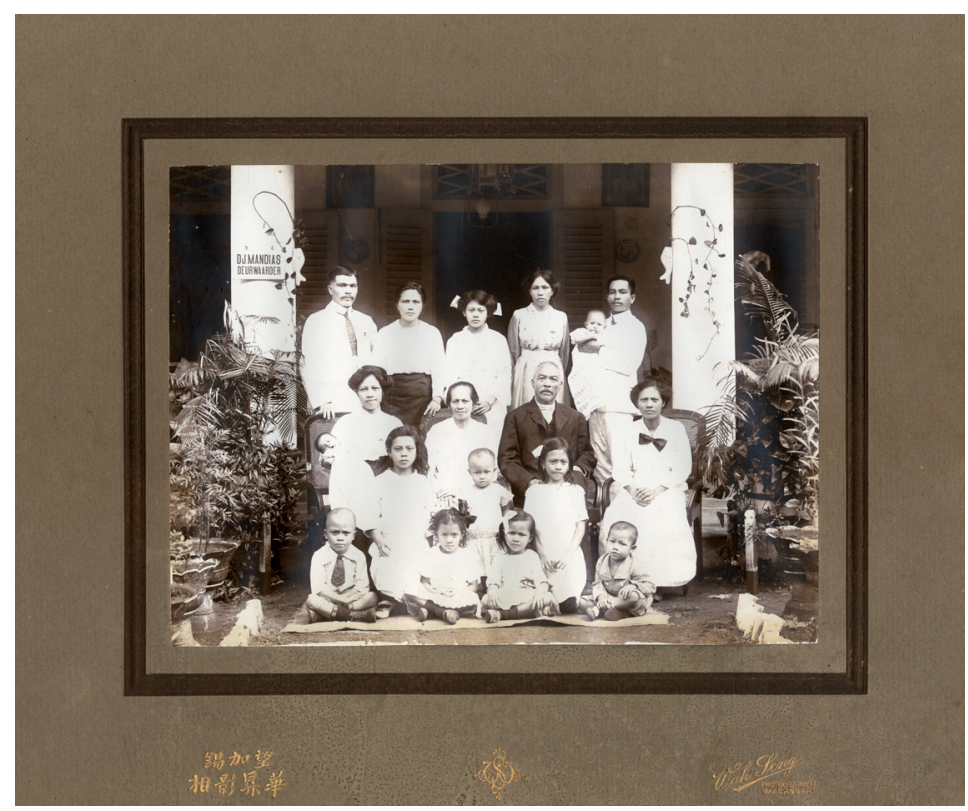

Image 12. Mandias family on the front veranda of the house in Makassar (photographer: Wah Seng; KITLV collection: 183913).

The family dressed for the occasion and the careful positioning of each family member also enhances to the formal atmosphere of the portrait. As Image 13 shows, Chinese photographers were also sent for by the kraton. The portrait was made by King Ming in the Solo kraton portraying three Goesti Raden Ajoes and their husbands around 1920.

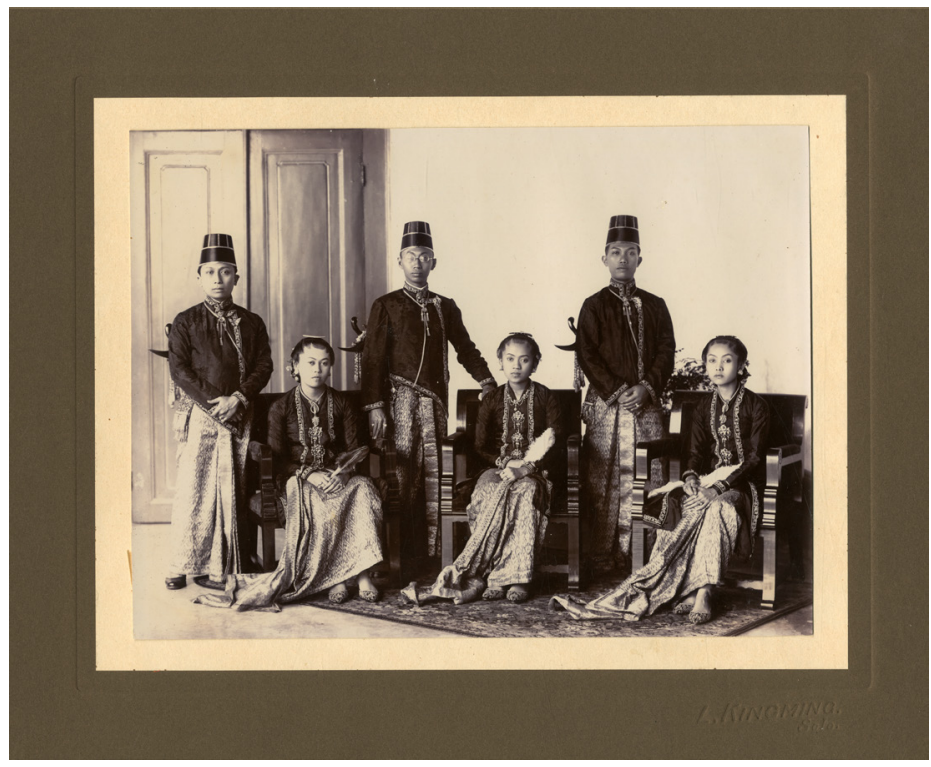

Image 13. Three Goesti Raden Ajoe's and their husbands in Jogjakarta, around 1920 (photographer: King Ming; KITLV collection: 116668). 
Interestingly, the back of the photo card gives only the names of the female members of the party. Even though the photo was taken inside the kraton itself, in surroundings very familiar to the sitters, the Javanese costumes and the way the sitters are posing makes it a very formal photograph. The fact that the image is mounted on a stiff card $26.5 \times 31.5 \mathrm{~cm}$ means that it would have been unsuitable to put into a family album. The portrait might have been displayed in one of the quarters of the kraton, in a place where it could be viewed by family members and visitors. In short, the materiality of the photograph and the obviously staged presentation by the sitters are indications that the photograph was intended to be read formally at the time. The portrait was the result of cooperation between King Ming and the members of the kraton family. It would be interesting to know whether the formal way the kraton party was portrayed accorded with Javanse (kraton) aesthetics. King Ming ran a commercial studio which was a competitor of other (European) photographers. Apparently, he was deemed a suitable photographer to work with the kraton family, since he was summoned on more than one occasion.

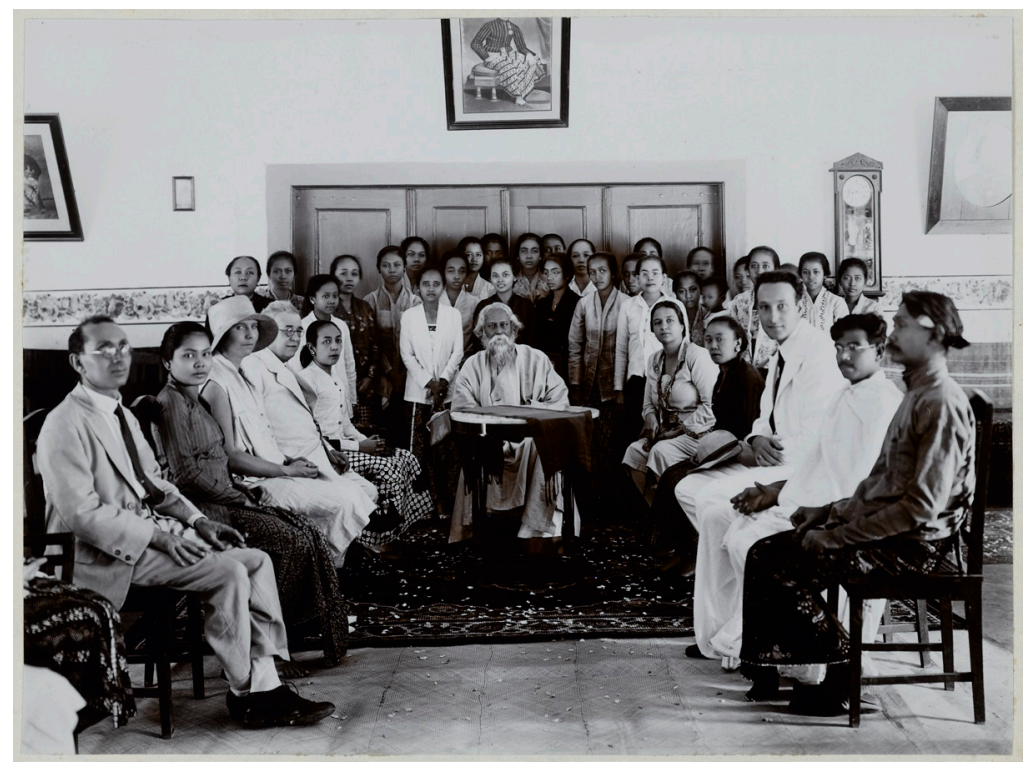

Image 14. Rabindranath Tagore with his travel party during their visit in Jogjakarta, 1927 (photographer: Che Lan; KITLV collection: 17780).

As shown, Chinese photographers were involved in personal or domestic commissions. Chinese photographers were also involved in commissions outside the domestic atmosphere. Commissions were given to commemorate a certain occasion, documenting a particular event. The daily, Het Nieuws van den Dag, for example, reports on the front page on 14 December, 1907, that the photographer Tan Tjie Lan had photographed the visit of the Chinese imperial commissioner, Yang Shi Chi, at the railway station near Koningsplein in Batavia. The newspaper stated that Tan Tjie La's services had probably 
been called upon to ensure that the Chinese officials would have a tangible souvenir of their trip to the Indies. Another visit which also did not pass unnoticed by the newspapers was the visit to Java and Bali of the Indian poet and philosopher Rabindranath Tagore in 1927.

Image 14 taken by Che Lan portrays Tagore in the centre surrounded by his travel party, Arnold Bake and his wife, and a large group of Javanese women. The photo was taken in Jogjakarta, possibly in the Java Museum.

At some events only one photograph was taken, or survived, as a souvenir of the occasion. Of course, other occasions were more thoroughly documented photographically and hence there is more than one single image of them. The Batavia-based photographer Oeij Eng Tian made some pictures when C.W.A. Abbenhuis succeeded H. van Lochem as Resident of Batavia on 30 September, 1940. The sequential numbers for repeat orders noted by Oeij Eng Tian on the back of the photos indicate the successive stages of the posing, which is also confirmed by the captions in the album.

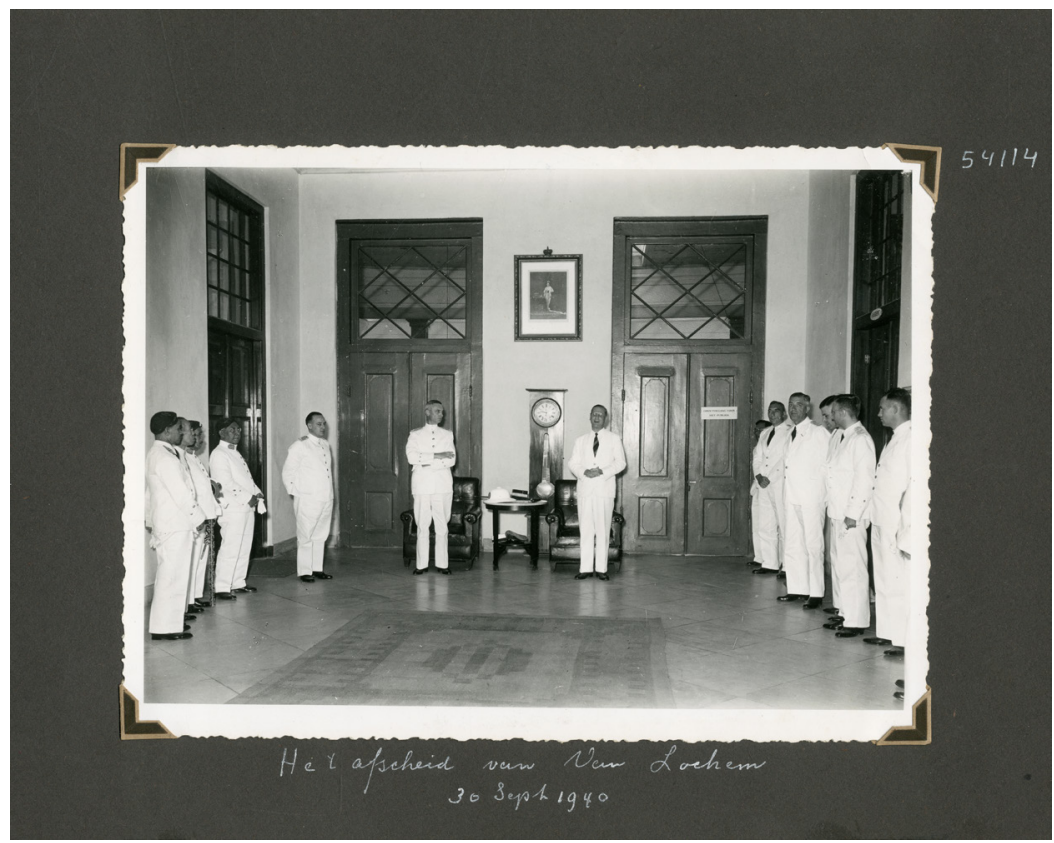

Image 15. Appointment of C.W.A. Abbenhuis as Resident of Batavia, September 1940 (photographer: Oeij Eng Tian; KITLV collection: 54115).

Image 15 tells the viewers it is Van Lochem's farewell. In the following photograph, the compiler elaborates on Abbenhuis' appointment to office, referring to him in the third person: "Mr. C.W.A. Abbenhuis, the new Resident of Batavia. The succession to office and farewell to Van Lochem. Residency Office, Batavia, 30 September, $1940 "{ }^{\prime 10}$ Interestingly enough, these photos are part of a private snapshot album, possibly compiled by either Abbenhuis or

10 The image can be found under KITLV collection: 54115. 
his wife. Since the overall content of the album captures Abbenhuis and his wife during their official work visits, the captions in the album add to the formal atmosphere of the content, especially when the "main characters" refer to themselves in the third person. As mentioned above, these photos of Abbenhuis' memorable appointment are part of a snapshot album, possibly intended to be viewed in the intimate family circle. As Edwards and Hart suggest (2004: 11), these type of albums do not have the performative qualities to be read formally.

Another album containing fifteen photographs by Tan Tjie Lan was meant to be displayed on a table and hence be viewed more formally. Around 1900, the STOVIA (School for the Training of Native Physicians) in Batavia commissioned Tan Tjie Lan to make a series of exterior and interior photos of the school, plus some group portraits. The reason for this commission was its move to its new premises on the Hospitaalweg in 1899. The attention which was paid to the composition of the album would have made it a real showpiece in its day; each page contains one large photo $(19 \times 25 \mathrm{~cm}$ on average) with printed captions, as can be seen in Image 16. The quality of the compositions adds to the performative quality of the album. Moreover, the fact that the photographic print is an albumen print without the more expensive gold toning means that the prints have been less long lasting. The gold toning would have reduced the effects of fading and general deterioration in the course of time.

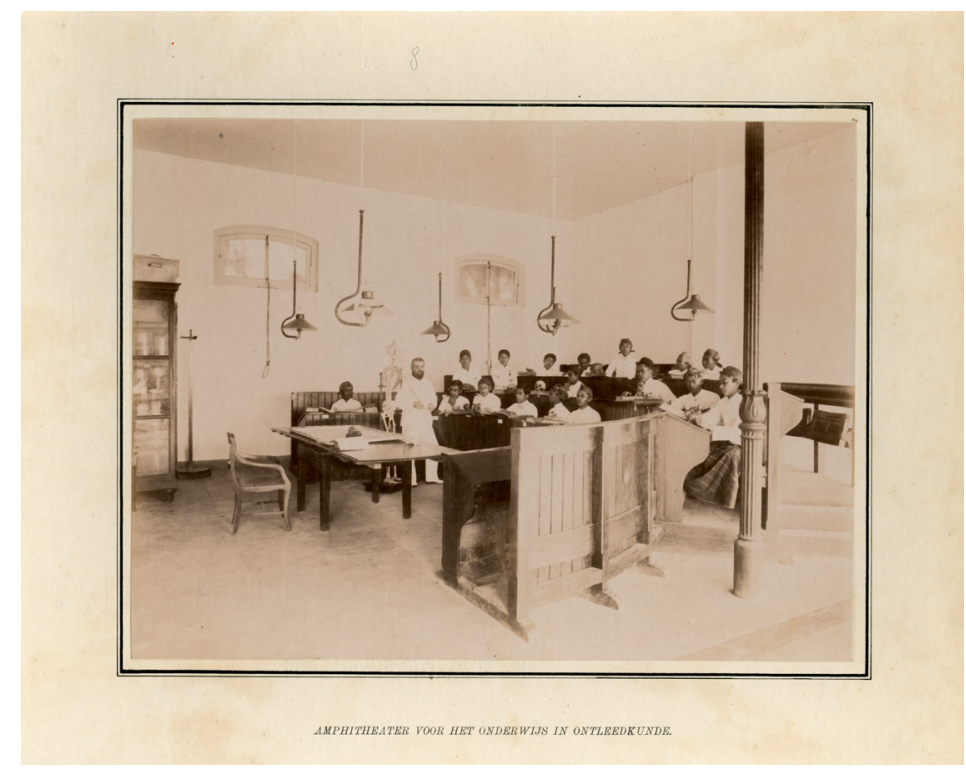

Image 16. Director H.F. Roll and students in the anatomical theatre of the STOVIA in Batavia, around 1900 (photographer: Tan Tjie Lan; KITLV collection: 35814). 
As shown above, Chinese photographers were not just dependent on customers visiting their studios. They also accepted outside commissions. The domestic atmosphere of the sitters and the official occasions in which the sitters were involved had to be recorded in commemorative photographs, Chinese photographers and their European counterparts alike were called upon to lend their services. Urban areas like Jogjakarta, Solo, and Batavia teemed with professional photographers, European as well as Chinese. Members of both the European and Javanese elites commissioned Chinese photographers, thereby letting the Chinese photographer into "their world". The presentational forms, such as photo cards and show-piece albums, revealed the work of the Chinese photographers to viewers outside the "closed" atmosphere of the home or the office. Chinese photographers were active in various social strata, directly (at the time of the photo shoot) and indirectly (when the photo was viewed).

The two categories discussed so far, the studio photographs and those produced outside, were the result of a cooperation between the portrayed and the photographer. The presence of the camera was obvious; the sitters performed in front of the camera. In the third and final category, the commercial or instant photographs, the presence of the camera is less evident; and these photographs were not the result of cooperation.

\section{FROM FESTIVITIES TO SOUVENIRS OF DISASTERS AND SCENIC POSTCARDS}

Professional photographers also sold commercial or instant images of urban points of interest and picturesque landscapes. Since photography was only practised by professionals and a few (well-to-do) amateurs in the nineteenth and early-twentieth century, the average inhabitant would buy their images from a studio. However, after the 1910s cameras became more affordable and easier for amateurs to use. Albeit snapshot photography took off in this period, instant photographs were still produced and Chinese photographers were also involved in the commercial field, but not on a large scale, as I shall demonstrate in this section.

Two groups can be can be distinguished in commercial photography. Firstly, the town- and landscapes which were relatively timeless. Secondly, the images which were produced to celebrate a particular event. Hwa San, operating from Cheribon photographed the construction of a bridge over the Tjimanoek River near Madjalengka around 1915. ${ }^{11}$ Photographer Mew Fong took a photograph when his hometown, Padang, flooded on 24 November, 1911. Mew Fong inscribed the event, date and location in Indonesian on the negative of the photograph, and this would consequently appear on every single print and thereby commemorating the unfortunate event precisely. The "No. 2" in the caption indicates that Mew Fong took more than one single photograph of the flood. However, only one image has ended up in the KITLV collection. ${ }^{12}$ Another natural disaster in the Archipelago did produce a series of photographs. After the eruption of Mount Kloet in May

11 The image can be found under KITLV collection: 119085.

12 KITLV collection: 150894. 
1919, Studio Promemoria in Bondowoso produced a photographic reportage. The KITLV collection holds two albums entitled Erruptie Kloet (or the Kloet eruption). A reportage shows victims dead and alive, damaged infrastructure and properties and mudflows. As I have stated elsewhere, the albums were most likely used by Promemoria to show the viewers what was on offer. The layout of the photographs mounted in the albums follows the exact index of an order form which is part of the albums (Image 17).

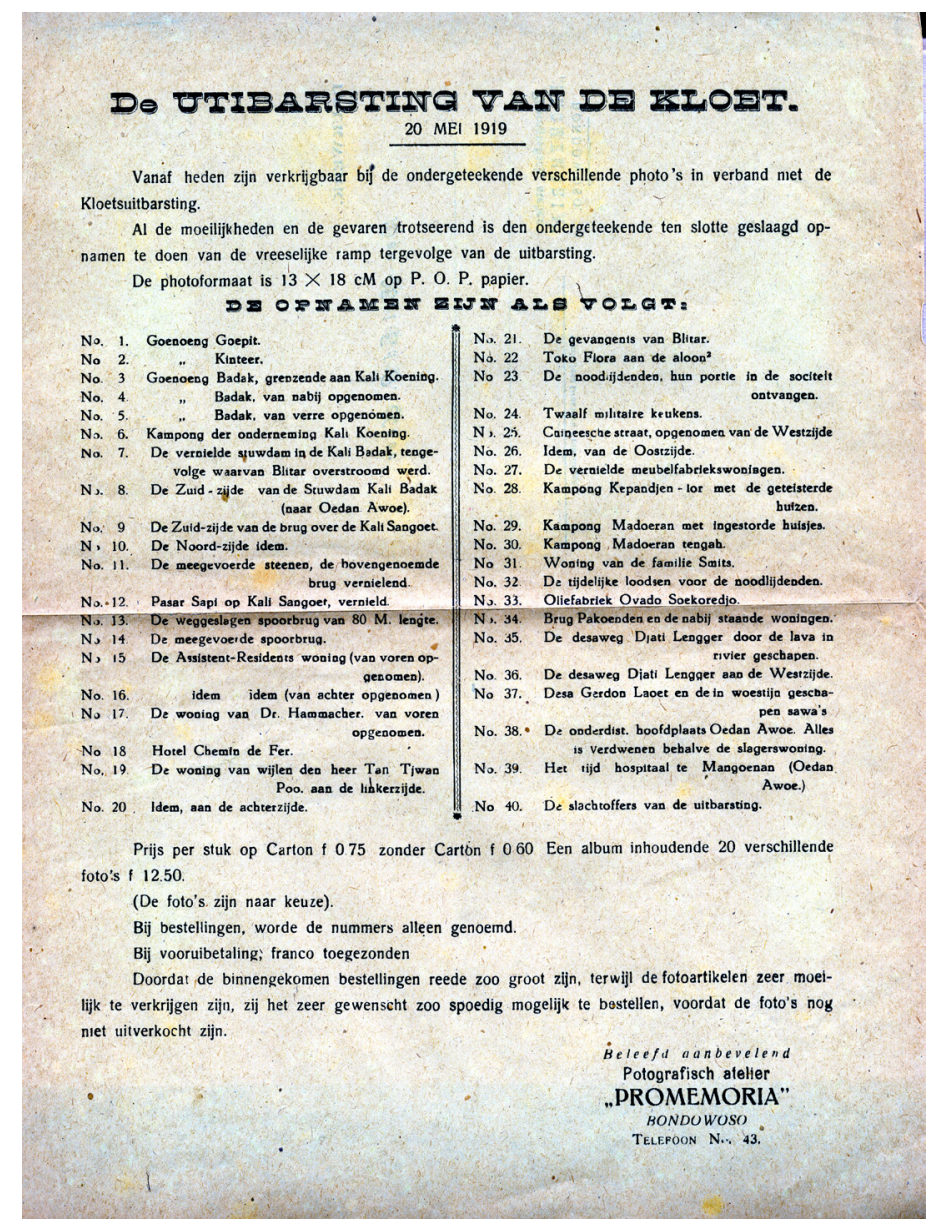

Image 17. Order form for the Kloet photos made after the eruption of May 1919 by studio Promemoria (KITLV collection: A 388).

The index of the order form is in Dutch, but the captions in the albums are in Indonesian. The bilingual explanations of the Kloet eruption made the photographs available to different consumers (Ouwehand 2014: 52-54). The order forms for these commercial photographs indicate that they were not necessarily made to be kept as personal souvenirs, but merely as disaster (tourism) souvenirs for customers who had not experienced the eruption personally. 
A photo reportage of a more festive occasion was made by Tan Tjie Lan in 1898. He photographed the decorations in Batavia to mark the inauguration of Queen Wilhelmina. A series of nineteen photographs can be retrieved from the KITLV collection.

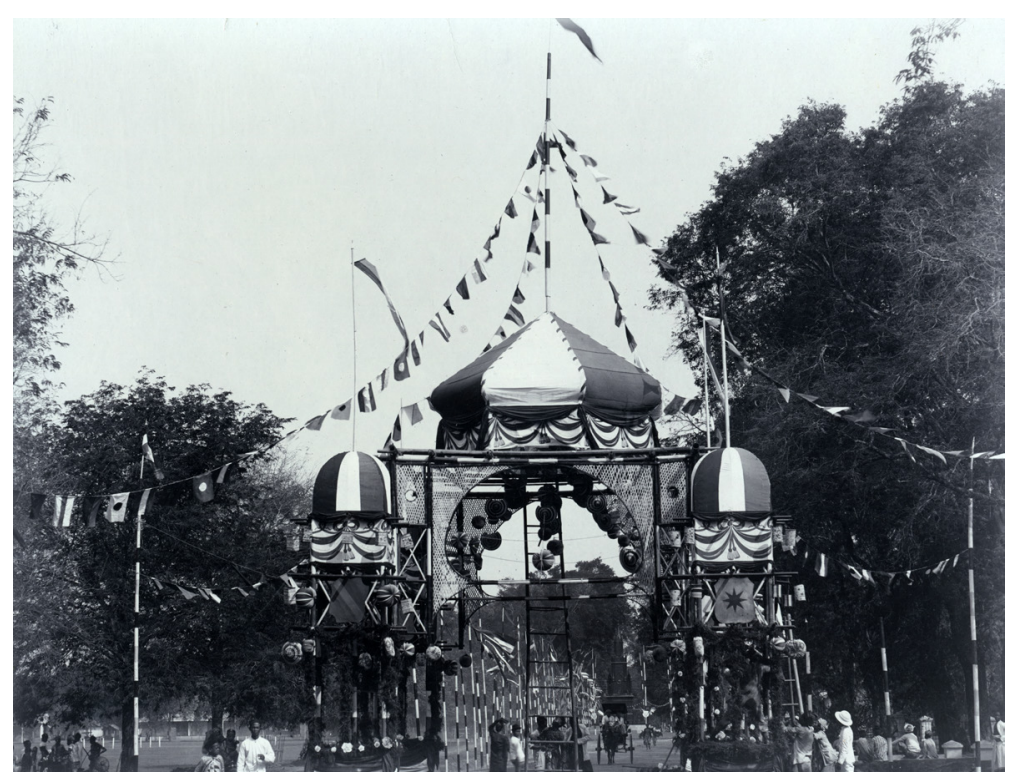

Image 18. Triumphal arch erected near the Waterlooplein in Batavia to celebrate the royal inauguration of Queen Wilhelmina in September 1898 (photographer: Tan Tjie Lan; KITLV collection: 114143).

Image 18 shows one of the many decorated ceremonial arches especially erected to celebrate the occasion. Tan Tjie Lan mounted the large images $(18.5 \mathrm{x}$ $23.5 \mathrm{~cm}$ on average) on cards printed for his studio. These festive photographs would have been perfect souvenirs for people who had participated in the celebrations. Since the provenance of all the souvenirs of this event is unknown and they are not integrated into a family or a travel album, it is difficult to hazard any guess about who the purchasers of these images might have been. However, the advertisements placed by the photographers in newspapers might reveal some information. Tan Tjie Lan was one of the few Chinese photographers who advertised on a regular basis in the Dutch-language Indies newspapers. The daily, Bataviaasch Nieuwsblad, advertised not only his portrait photography but also his views of Batavia and, interestingly enough, the availability of slippers (Image 19). 


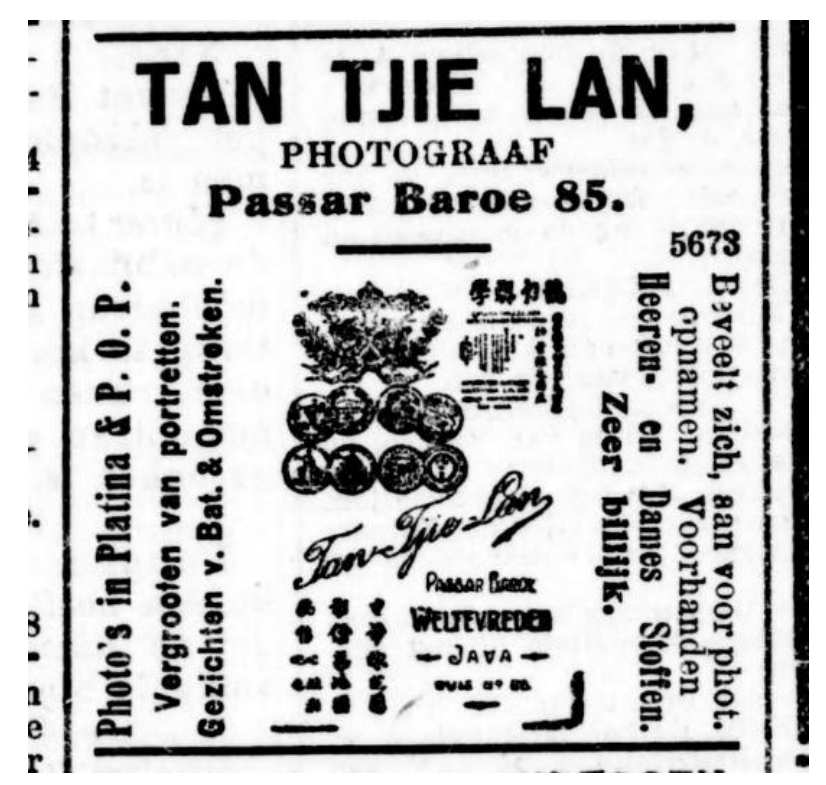

Image 19. Advertisement by photographer Tan Tjie Lan published in the daily Bataviaasch Nieuwsblad in June 1911.

As did those of his European counterparts, Tan Tjie Lan's advertisements in a Dutch newspaper were clearly directed at the European echelon of the colonial society. It might be assumed that the fact Tan Tjie Lan advertised his views and landscapes might have contributed towards the widespread distribution of these images; an assumption which could be construed from the KITLV collection. However, this is not the case. Of course, Tan Tjie Lan might have sold his commercial photographs to a clientele not represented in the KITLV collection, but, as stated earlier, he did have contacts with the higher (European) strata in Batavia. Among them would certainly have been people who would also have been interested in commercial views and landscapes. However, traces of this interest are only found incidentally in the collection.

Be that as it may, the KITLV collection does hold two examples of massproduced, instant photographs and photographic postcards from late-colonial Java: produced by Studio Malang, owned by Ong Kian Bie, and Toko Liem. In case of the latter, it is not clear whether it was a shop selling photographic postcards of Sarangan or whether Toko Liem operated a photo studio. If we trace the different trajectories of the images by Studio Malang and Toko Liem, one fact is obvious, the same images attracted different (elite) buyers. The aristocrat P.J. Winter who made a study tour to the Indies in 1931 bought commercial photos from different studios as tourist souvenirs. From Studio Malang he obtained a total of seven town views and two photographic postcards of the Singosari Temple near Malang. Local (European) inhabitants were also attracted by the urban highlights and impressive landscapes. Mrs Bijleveld-Visser who worked as a dentist and was married to the army 
surgeon, J.W. Bijleveld, integrated different views into her family albums. Panoramic photo (Image 20) by Studio Malang of the Spoorstraat (Railway Street) shares an album page with five snapshots of their home in Malang, commemorating their recent move to "our house in Malang on 2 December $1933^{\prime \prime}$ as the caption reveals.

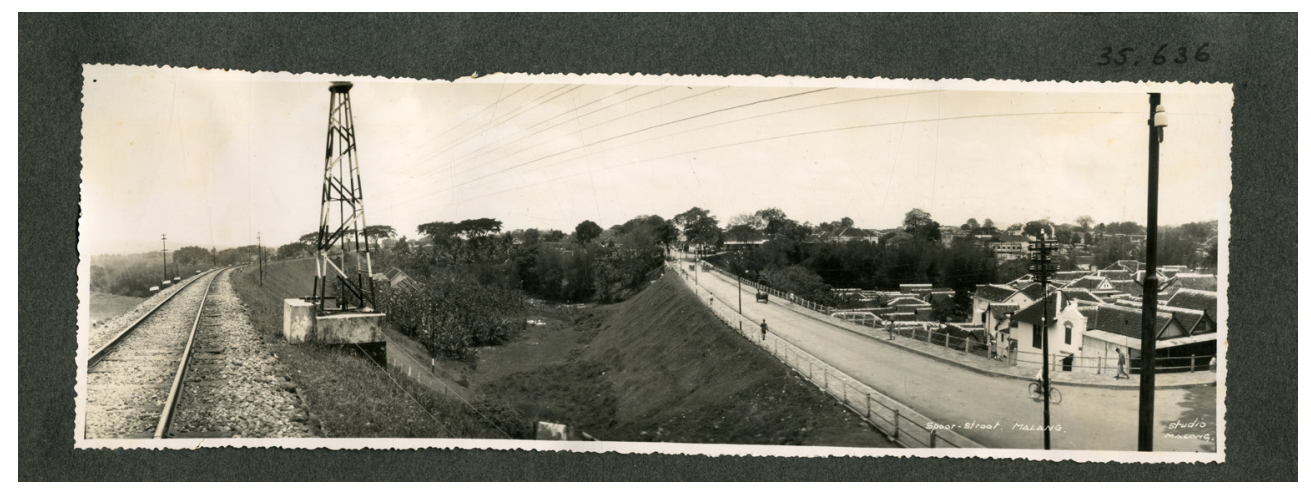

Image 20. Panorama photograph of Spoorstraat in Malang, around 1930 (photographer: Studio Malang; KITLV collection: 35636).

The Bijlevelds' personalized the mass-produced commercial views of the Malang Studio. Or, as Nordström (2004: 88-92) puts it, it is the captions which "author" the commercially produced photographs and turn them into a "specific personal experience", thereby transforming them into autobiographical objects. Eleven photos by the Malang Studio ended up in three Bijleveld-Visser family albums. A trip to Lake Sarangan in the cooler mountainous area near Magetan resulted in a mixture of family snapshots and photographic postcards bought at Toko Liem. ${ }^{13}$

The majority of the photos in the KITLV by Toko Liem collection were produced as photographic postcards; photos, as we have seen, suitable to put in a (family) album or be sent as a postcard to family or friends in the Archipelago or the Netherlands. Toko Liem sold picturesque views of Lake Sarangan, and Studio Malang also sold images of the popular Arendsnest Hotel (the Eagles' Nest Hotel) in the same location. The man or boy herding the buffaloes at the bank of Lake Sarangan makes a very idyllic scene (Image 21). 


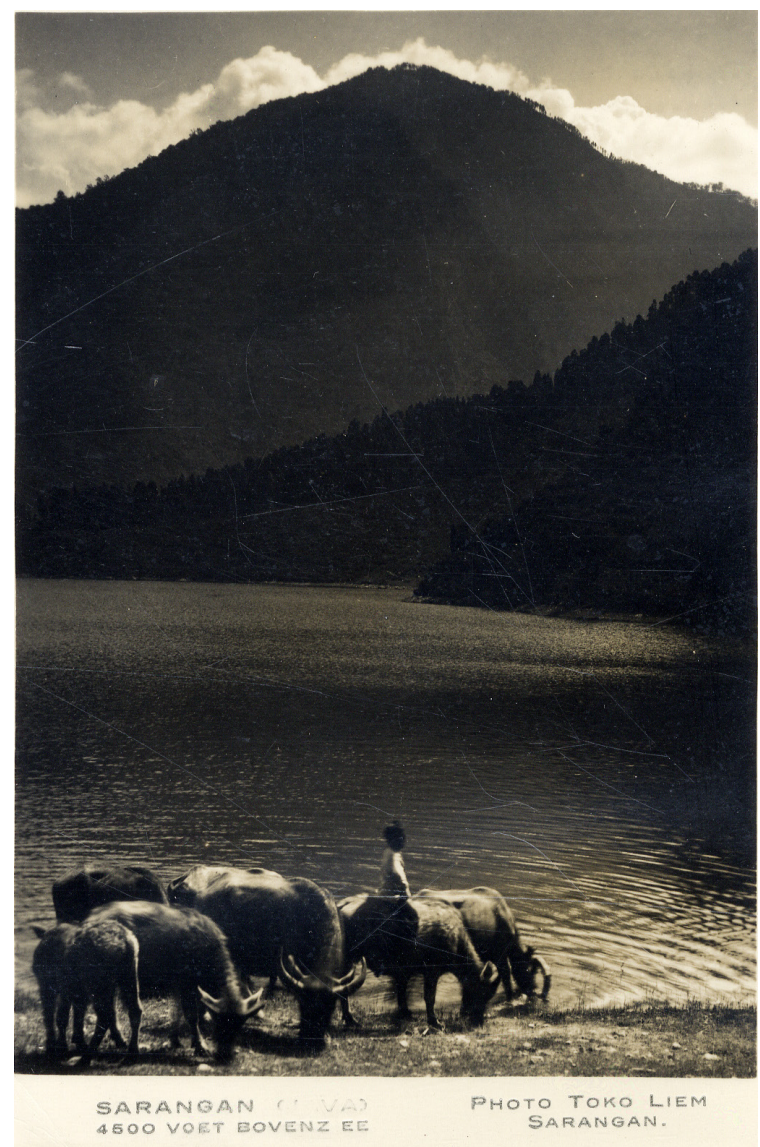

Image 21. Photographic postcard of buffaloes on the shore of lake Sarangan, around 1935 (photographer: Toko Liem; KITLV collection: 182170).

The brief note written on the back of the postcard by Tieneke associates the scene with her brother's experience of sitting on a buffalo by the lakeside. Their mother made a picture to commemorate the ride, as Tieneke noted, but it was not yet known whether the images were a success, since the film had not yet been developed. The choice for this particular photographic postcard by Toko Liem corroborated a personal experience which was shared with the receiver of the card.

Even though Studio Malang also made commissioned portraits, interestingly enough it is its commercial scenes which predominate in the KITLV collection, particularly the street scenes of Malang. ${ }^{14}$ As the daughter of Ong Kian Bie explained, he was interested in photographically recording the changes over time of his hometown (Tang-Ong 1996). Studio Malang advertised regularly in the Chinese-Indonesian newspaper, Sin Po, between 1936 and 1942. Their advertisements also emphasized the commercial 
photographs. By transferring 1.20 guilders to the Studio's account, twelve "artistic photos of Java and Bali" would be sent (Sin Po 1938). Even though Studio Malang had set their sights on the Chinese-Indonesian inhabitants with its advertisements in Sin Po, photos by the Studio were widespread among an European (elite) clientele as well, for instance, P.J. Winter and the Bijleveld-Visser family. Although more study should be undertaken on the dispersion and content of advertisements placed by Chinese photographers in different newspapers, it seems that the main focus of the advertisements was on portrait photography and making commissioned photographs outdoors.

Finally, in a consideration of commercial photography roughly three topics can be distinguished: town views, landscapes and types. In the work of Chinese photographers the last subject is almost absent in the KITLV collection; with a few exceptions such as the photograph taken in Denpasar by Tae San, who captured two Balinese women who had just visited the market. On the face of it this might not seem surprising, since Chinese photographers were less involved in commercial or instant photography than were their European counterparts. Studio Malang and Toko Liem are an exception. The message from the KITLV collection is that the taking of instant images was only sporadically undertaken by Chinese photographers.

\section{CONCLUDING REMARKS}

Chinese photographers certainly added to the visual colonial landscape, mainly through their involvement in portrait photography. The image that Chinese photographers served less elite clientele is not valid, at least on the basis of the photographic material available in the KITLV collection. Chinese photographers based in the sultanate cities of Jogjakarta and Solo were definitely involved in the networks of the Javanese elite. King Ming and Che Lan were not exceptions; Saw Chan in Solo and TaeSan in Denpasar, for example, also had access to more exalted circles and made portraits of the indigenous elite. Many of their clientele were also drawn from members of the higher echelons of Europeans and Chinese. Interestingly, in cities such as Batavia and Jogjakarta this clientele could choose from a wide range of photographers, both Chinese and European. Whereas in other, more remote areas or smaller towns, such as Karimoen or Bondowoso, the choice of photographic studios was less broad and commissioning a Chinese photographer would have been a logical step. Whether Chinese photographers were cheaper or worked for the same prices as their European counterparts has still not been established . Prices were rarely advertised, and photographic cards or envelopes do not give any hints. Either way, considering the different sitters who found their way into Chinese studios, it becomes clear that Chinese photographers were not barred from elite networks and consequently competed with their European counterparts, especially in Java.

As the portraits are the result of the interaction between sitter(s) and photographer, the portraits do not seem to follow a specifically "Chinese way" of photographing. European, Javanese and Chinese aesthetics, that is, 
the choice of clothing, backdrops, furnishings and location, for instance, were part of the performance by the sitters. Hence, the portraits reflect not so much a European, colonial or Chinese gaze. In fact, the term commercial gaze seems more relevant to the study of Chinese photographers, since the aesthetic input of both the photographer and the portrayed was relevant.

Although the trajectories of the photographs discussed have been picked up the moment the images were added to the KITLV collection, their provenance and route to the archive of each and every one of them, is not clear. The concept of materiality as suggested by Edwards and Hart (2004: 3-4) has uncovered particulars about their use over time. Presentational forms such as cards, notes jotted down at the back, etcetera, show that the photographs were used as exchange objects, useful in maintaining the Javanese-European network, for instance. On account of their production of portraits, Chinese photographers were also indirectly part of this network. Chinese photographers participated in different social strata at different moments in time: at the time of the photo shoot and when their photographs were being viewed.

\section{REFERENCES}

Edwards, Elizabeth and Janice Hart. 2004. “Introduction; Photographs as objects", in: Elizabeth Edwards and Janice Hart (eds), Photographs, objects, histories; On the materiality of images, pp. 1-15. London/New York: Routledge.

Knaap, Gerrit. 1999. Cephas, Yogyakarta; Photography in the service of the Sultan. Leiden: KITLV Press.

Kreuger, C. 1923. “Indische ervaringen”, Lux, Foto-tijdschrift 34: 32-34.

Liu, Gretchen. 1995. From the family album; Portraits from the Lee Brothers Studio, Singapore 1910-1925. Singapore: Landmark Books.

Morris, Rosalind C. 2009. "Introduction. Photographies East; The camera and its histories in East and Southeast Asia", in: Rosalind C. Morris (ed.), Photographies East; The camera and its histories in East and Southeast Asia, pp. 1-28. Durham/London: Duke University Press.

Nieuwenhuys, Rob. 1988. Met vreemde ogen; Tempo doeloe - een verzonken wereld; Fotografische documenten uit het oude Indië. Amsterdam: Querido.

Nordström, Alison. 2004. "Making a journey; The Tupper scrapbooks and the travel they describe", in: Elizabeth Edwards and Janice Hart (eds), Photographs, objects, histories; On the materiality of images, pp. 81-95. London/ New York: Routledge.

Ouwehand, Liesbeth. 2014. "Disastrous encounters; Photographic representations of catastrophe in the Dutch East Indies", Moving Worlds; A Journal of Transcultural Writings 14: 46-60.

Pinney, Christopher. 1997. Camera Indica; The social life of Indian photographs. Chicago: The University of Chicago Press.

Protschky, Susie. 2012. "Tea cups, cameras and family life; Picturing domesticity in elite European and Javanese family photographs from the Netherlands Indies, ca. 1900-42", History of Photography 36: 44-65. 
Radersma, J. 1901. "De camera in Indië", Lux, Geillustreerd Tijdschrift voor Fotografie 13: 441-444.

Straatman, H.G. 1915. "Fotografeeren in Indië" , Lux, Foto-tijdschrift 26: 201-205.

Strassler, Karen. 2007. "Photography's Asian circuits”, IIAS Newsletter 44: 4-5.

Strassler, Karen. 2008. "Cosmopolitan visions; Ethnic Chinese and the photographic imagining of Indonesia in the late colonial and early postcolonial periods", The Journal of Asian Studies 67: 395-432.

Strassler, Karen. 2010. Refracted visions; Popular photography and national modernity in Java. Durham/London: Duke University Press.

Strassler, Karen. 2015. "Modelling modernity; Ethnic Chinese in the ethical era", in: Susie Protschky (ed.), Photography, modernity and the governed in late-colonial Indonesia, pp. 195-222. Amsterdam: Amsterdam University Press.

Tan-Ong, Ai Ling. 1996. Exhibition catalog; Photographs from Ong Kian Bie, Studio Malang. Jakarta: Erasmushuis.

Wachlin, Steven. 1989. “Grootschalige fotostudio's en amateur-fotografie/ Large scale studios and amateur photography", in: Anneke Groeneveld, Paul Faber, and Michael Gibbs (eds), Toekang potret; 100 jaar fotografie in Nederlands Indie 1839-1939 / Toekang potret; 100 years of photography in the Dutch Indies 1839-1939, pp. 121-164. Amsterdam/Rotterdam: Fragment Uitgeverij/Museum voor Volkenkunde.

NEWSPAPERS

Bataviaasch Nieuwsblad 8 June 1911.

Het Nieuws van den Dag voor Nederlandsch-Indië 14 December 1907.

Sin Po 8 January 1938. 